\title{
Society in Front of 2 Enemies: COVID-19 \& Climate Collapse/Their Impact on Shipping Industry
}

\author{
Alexandros M. Goulielmos ${ }^{1,2}$ \\ ${ }^{1}$ Former Professor of Marine Economics, University of Piraeus, Department of Maritime Studies, Faculty of Maritime and \\ Industrial Studies, Piraeus, Greece \\ ${ }^{2}$ Professor Emeritus of Shipping, Transport and Logistics Department, Business College of Athens, Athens, Greece \\ Email: ag@unipi.gr,am.goulielmos@hotmail.com, agoulielmos@bca.edu.gr
}

How to cite this paper: Goulielmos, A. M (2020). Society in Front of 2 Enemies: COVID-19 \& Climate Collapse/Their Impact on Shipping Industry. Modern Economy, 11, 2006-2026. https://doi.org/10.4236/me.2020.1112134

Received: November 5, 2020

Accepted: December 20, 2020

Published: December 23, 2020

Copyright $\odot 2020$ by author(s) and Scientific Research Publishing Inc. This work is licensed under the Creative Commons Attribution International License (CC BY 4.0).

http://creativecommons.org/licenses/by/4.0/

\section{(c) (i) Open Access}

\begin{abstract}
This paper analyzed the impacts of Covid-19 in 2020 on: a) Global economy, b) Greek economy, c) Greek society and d) Shipping Industry. The impacts were grouped in negative and positive. Analyzed is also the impact of Climatic Change or rather Collapse by writing-down in a table the major hurricanes etc. since 1780 and the cyclone "Janus", which hit "Greece". We revised the principle of Sustained Development, and formed a model entering Environment in production function. We proposed the establishment of the "Sustainable City". A "digital citizen" emerged in our theory, and we showed his/her future needs in small robots, re-skilling and others. The coming global war will be over "data" prophesized. The firm decision of EU, to protect EU's environment by pouring millions of $€$ by issues of green bonds and other measures, presented.
\end{abstract}

\section{Keywords}

COVID-19 Negative \& Positive Impacts, Climatic Change and Collapse, A Model with Environment as Factor, Sustainable Development, The Sustained City, The "Digital Citizen", EU Environmental Policy, Humanitarian Considerations

\section{Introduction}

Humanity is facing 3 strong enemies during peace. The 2 are the COVID-19 and the Climate collapse-CC. The third is not an enemy, but its possession will cause

${ }^{1} 1.5 \mathrm{~m}$ from COVID-19 (end 2020); 1/2 $\mathrm{m}$ from main hurricanes \& storms (Appendix 1). 
a global war, i.e. the "data". Those killed by ${ }^{1}$ the above two enemies approached by $20^{\text {th }}$ November 2020 the 2 million! While COVID-19 is a newcomer, and in its second stronger wave in Nov. 2020, the unfolding of CC is almost 50 years old. The "Club of Rome", (founded in 19682), rung the bell in 1972, for the risk coming from polluting the global environment!

Is really our climate an enemy"3? A regular information about climate's condition is provided by IPCC ("International panel on climate change") ${ }^{4}$, among many others. The CC process is as follows: when the oil, and other fossil fuels, burned $^{5}$, release gases to atmosphere, mainly $\mathrm{CO}_{2}$, causing the "greenhouse effect". This keeps planet's temperature inside atmosphere, warming - planet - up. The ice in the Poles melts, and uprises sea surface, so that less land to be available to Governments; but also more sea (Antarctic). The warming-up of the planet, helps fires, aided by the dry material laid-up in the woods, from the frequent hot summers with burning heats. Fires destroy remaining trees, which retained soil. More heavy and frequent rains cause the floods.

Humanity is a victim of its prior decisions, we believe, as it became a "life-sentence prisoner" of 2 main sources of energy: oil and coal (Figure 1).

As shown, oil is on top, with about a $32 \%$ share. Coal had about a $28 \%$ share (2011) with an increased consumption since 2002 and almost unchanged since 1986 (29\%). More important is that coal's share in 2011 was higher since 1969 (not shown)! Natural gas had a share of about 24\% (2011) against 20\% in 1986. Renewables are hardly shown (light red). Moreover, total energy consumption increased by $64 \%$ in 25 years, indicating the global hunger for energy ${ }^{7} \ldots$ Coal was still, (in June $2020^{8}$ ), the single largest source of power generation with $36 \%$ !

In addition, the global $\mathrm{CO}_{2}$ emissions rose from 29,745 tons to 34,169 (2009 2019), or $\sim 15 \%$. While OECD countries and $\mathrm{EU}$ reduced $\mathrm{CO}_{2}$ emissions, from 12,508 tons to 12,012 (share in total: $35 \%$ ), and from 3830 to 3330 , non-OECD countries increased their emissions from 17,238 tons to 22,157 (2009-2019;

\footnotetext{
${ }^{2} \mathrm{~A}$ "common concern about the future of humanity" (Dieren (editor) (1995)).

${ }^{3}$ Sun's ultraviolets rays cause skin cancer due to man-made holes in ozone layer... used to protect earth from sun's radiation. The holes are caused by all kinds of lead aerosols. Australia was hit in the past during summers.

${ }^{4}$ Established in 1988 by UN https://www.ipcc.ch/.

${ }^{5}$ Pollution occurs in: air, water, soil and sound (noise). It makes environment fatally-dirty for humans, plants, animals \& other organisms. Meat, plastic containers, dirty-fish, eggs, yoghurt, cheese, breathing polluted air, drinking unclean water \& radiation may cause cancer. We know that from Chernobyl (1986) \& Fukushima (2011). The first killed from 4,000 to 60,000 depending on estimation. Fukushima accident killed (earthquake plus tsunami): 18,500. Pregnant women led to abortion due to Chernobyl, including Greeks. A... positive impact of Chernobyl was that certain Governments (e.g. Germany) looked for, other, than nuclear, sources of energy (e.g. Sun). The top 3 nuclear-energy-consuming countries in 2011 were: USA 31\%; France 17\%; Russian Fed. 6.5\% (=54.5\%) (source: BP statistical review, 2012). Of course, the use of nuclear energy for medical purposes has to continue.

${ }^{6} \mathrm{~A}$ warming-up of the air surrounding earth due to the heat trapped.

${ }^{7}$ All strong nations flirt with ... nuclear weapons (Russia; Iran; N Korea; China etc.)!

${ }^{8} \mathrm{BP}$ 's CEO suggested using available methods \& technologies: renewable energies, electrification, hydrogen, carbon (captured \& stored), bioenergy. We thank BP for providing us freely and promptly its statistics on line.
} 


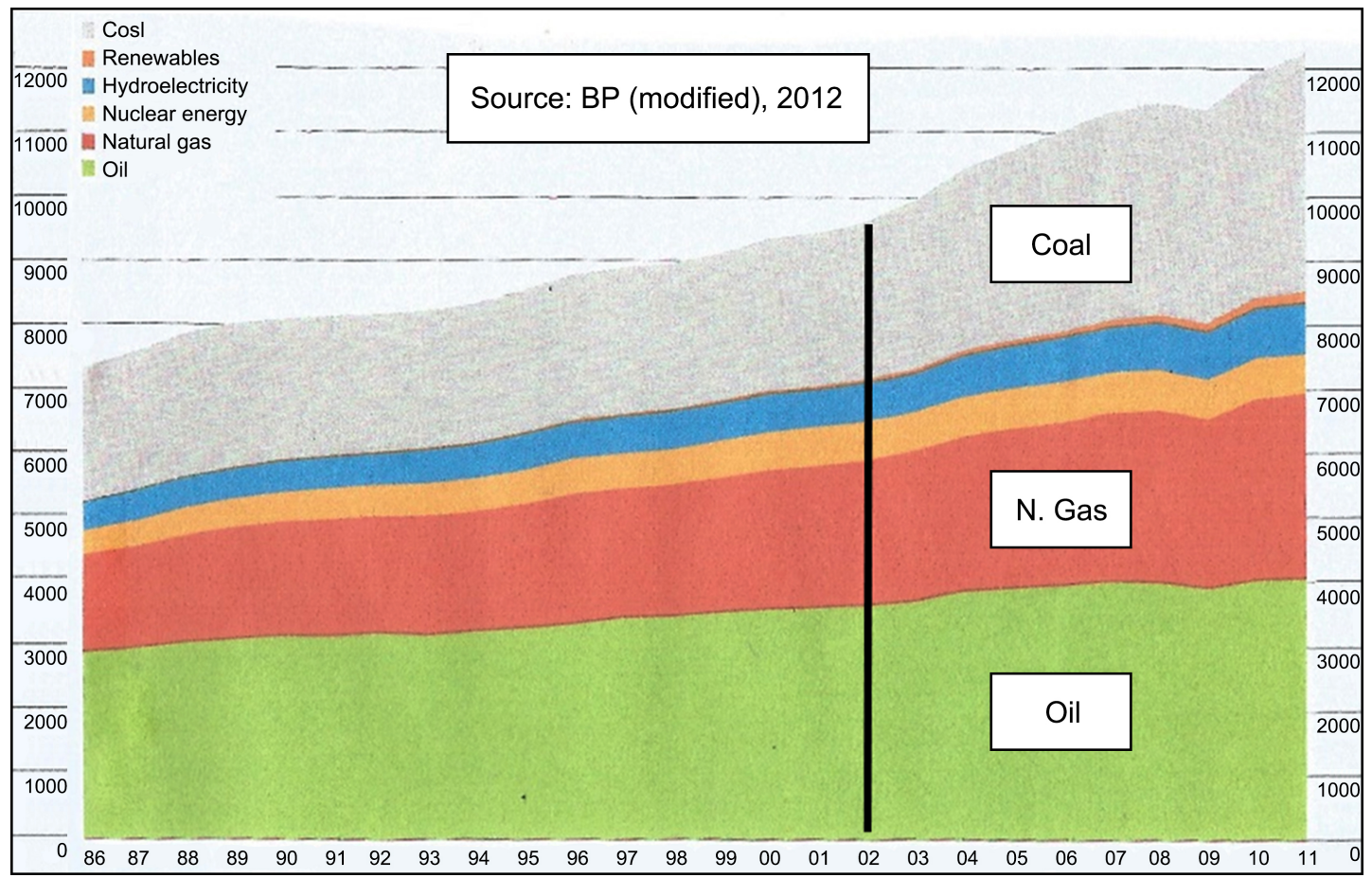

Figure 1. World energy consumption, 1986-2011 (million tons of equivalent oil).

about 29\%) (65\% in total). The following countries increased their emissions: China (about $28 \%)$, India $(+55 \%)$ and Russia $(+6 \%)$, while USA reduced them (6\%).

Moreover, diesel is mainly used to produce electricity, and boil the water of millions of central heatings ${ }^{9}$ worldwide $^{10}$. This means that electricity must be produced by non-fossil fuels. Governments have to oblige immediately new houses and buildings to use gas.

Have we to move to smarter cities, chosen from the "Smart City Index" $\left(\mathrm{IMD}^{11}\right)$ ? Athens got the... $99^{\text {th }}$ position with Singapore, Helsinki and Zurich in the first 3 positions (2019; internet).

Our contribution, we believe, is in the matter of sustainable development where we made new assumptions, like the one introducing ${ }^{12}$ environment's damage into production and profit functions; also, we added... sea as a factor of production in certain industries. Important is also that we assumed that resources are replaceable regardless if they are renewable, scarce, in extinction etc.

${ }^{9} \mathrm{GFC}$ - global financial crisis (2008-2013) — proved a friend of the environment with "austerity programs" cutting down diesel consumption by $2.5 \mathrm{~m}$ blocs of flats and houses (Greece).

${ }^{10}$ Interesting is the history of fuels: gas (since 2002) challenged oil (dominant since 1940s when the famous "Diesel" engine invented); oil challenged coal (2002); steam (in 1910s) won the battle with wind (dominant since 1869)!

${ }^{11}$ IMD compiles an index using 13,000 questionnaires over 109, called smart, cities, on a number of issues like health, safety, mobility, governance etc., brought-round by technology... (internet).

${ }^{12}$ Reviewing the 23 seminal papers in Pezzey \& Toman (2002)'s volume we saw that environment is no where in the production functions mentioned. Indeed, we turned the attention from Consumption, utility and welfare maximization, technical progress, capital and labor and so on, to Production, influenced by the interview made with the Greek Professor at Harvard Business School. 
or not. Society solves problems through "new" resources (like gas for oil; schist etc.).

\subsection{Aim and Organization of Paper}

This work aimed at showing: 1) The detrimental effects of the climate collapse-CC. 2) The adjustments required to sustain development and 3) the impacts (positive-negative) of COVID-19 on: global economy, Greek one, Greek society and Shipping industry. We formed a microeconomic model focusing exclusively on production function with... environment as a factor. Moreover, we analyzed the profile of what we named "digital-citizen"...

The paper is organized in 5 parts, after literature review. Part I, deals with the question: "what humanity has to sustain"? Part II, deals with COVID-19's indirect (positive) impacts on global economy/Greece. Part III, deals with COVID-19's indirect (negative) impacts on global economy/Greece. Part IV, deals with the climatic collapse in Globe, in EU and the relevant policies, and in Greece. Part V, deals with the... "digital citizen". Finally, we conclude.

\subsection{Literature Review}

Economists were aware of "sustainability", (defined below), since Malthus R. (in 1798), as he first worried about Britain's ability to feed an ever-increasing population with given land (Goulielmos, 2020). In 1865, Jevons W S (1835-1882) also questioned: "how Britain can sustain an increased energy consumption with a given supply of coal?"

Modern economists ignored sustainability. This is justified, as Economics, (1776), became a science by solving only 2 problems: "how unlimited needs can best be satisfied by limited means"; and "how limited resources can be best allocated among unlimited uses". In brief "what is" and not "what should be ${ }^{13}$ "...! We believe that the 2 above mentioned economics-positive and normative-had to be one!

Moreover, economists believed in "diminishing returns to scale" (Agriculture), a theory due to Adam Smith! This "law" unfortunately over-shadowed the other two: "constant \& increasing returns to scale" (Arthur, 1994), especially the last one. Economists believed that if resources are scarce, then their products will also be scarce (Pearce, 1992). Later (in 1940s) economists attempted to show how to grow GDP. Economic growth theories were strongly challenged by environmentalists (in 1972) warning that growth is limited!

Humans follow patterns, as Keyes wrote in 1936: when income increases, less

\footnotetext{
${ }^{13}$ The separation of economics in positive \& normative did wrong to economics. The "old-style" welfare economics was due to Pigou (1877-1959) (in "Economics of Welfare" in 1920). Pareto (1848-1923) introduced (1906) the "Pareto Optimum", proving that utility is not countable. The great supporter of positive economics was Friedman M (1912-2006) (1953: "the methodology of positive economics", in essays in positive economics, University of Chicago Press). The modern economist of normative economics, and Harvard University professor, is Sen A. K. (1933) (1970: "Collective choice \& social welfare", USA, Holden-Day). Interesting is Forbes in: "The remarkable rise of ESG”, 11/07/2019 (ESG = Environment = Social = Governance).
} 
is spent, proportionally, and more is saved (Goulielmos, 2018). Also, when income drops (or disappears) less is spent and saved. But less is also invested ${ }^{14}$, as the liberated factors of production from consumption, are fewer than those required to achieve a higher GDPt +1 . This is the capitalistic problem, marked out by Keynes, i.e. the deficiency of effective (money) demand. Hoarding brings death to Capitalism ${ }^{15}$ !

Meadows et al. (1972) argued that the growth ${ }^{16}$ (of global economy) is limited (TLTG)...! They used a "computer simulation model” of world economy related to natural environment, assuming limits in: agricultural land and production (per land unit); the amount of extractable (non-renewable) resources, and the ability of environment to assimilate waste ${ }^{17}$. They concluded: world economy will reach its growth limit by 2072 , but it was not a forecasting model!

Meadows et al., 20 years latter (1992), confirmed that global economy was beyond its growth limits (BTL)! This caused less controversy, as was considered a case of learning something from it, especially economists... Their 1972 limits to growth remained valid, requiring additional strength. Important is, however, that pollution came-out as a main concern...for the 1st time.

Common M (1995) pointed-out that 2 of the greatest problems, which humanity faced were poverty, and the threats against natural environment. Important is that Common held responsible... economic activity! Unfortunately, the threats at the time of Common, proved to be attacks now (2020). The "Brundtland report" of $\mathrm{WCED}^{18}$ (1987) alarmed politicians, for the $1^{\text {st }}$ time, defining: "sustainable development"-SD (analyzed below).

IMO preoccupied ${ }^{19}$ to reduce pollution to air from ships' emissions (Goulielmos-Giziakis-Christodoulou, 2014b, July). Shipping also had to establish a global levy scheme, as a solution (Goulielmos-Giziakis-Christodoulou, 2014a, Feb.). Shipping discusses about a mechanical method to retain sulfur from maritime

\footnotetext{
${ }^{14}$ Classics assumed that those saved $=$ those invested. Thus, it is not possible: $\mathrm{St}-1 \neq \mathrm{It}\{1\} \& \mathrm{Yt}=\mathrm{St}$ $-1+\mathrm{Ct} \neq \mathrm{Ct}+$ It $\{2\}$, where $\mathrm{Yt}=$ income; $\mathrm{St}-1=$ last year saving; $\mathrm{Ct}=$ consumption and $\mathrm{It}=\mathrm{in}$ vestment. The rate of interest equalizes It with $\mathrm{St}-1$. Here there is no demand deficiency, causing unemployment. In Keynes investors \pm savers; they invest, if expect to earn something (net) above real rate of interest, for the whole life of investment! If $\mathrm{I}_{\mathrm{t}}<\mathrm{S}_{\mathrm{t}-1}\{3\}$, then $\mathrm{Y}_{\mathrm{t}}<\mathrm{Yt}_{-1}\{4\}$. In Greece, in 2017, saving had a low share of $11 \%$ of GDP against 30\% in Slovenia, Hungary and Czech Rep.

${ }^{15}$ Except for thieves.

${ }^{16}$ Harrod and Domar (in 1940s) produced a growth model, beyond theories of "distribution of income" (Ricardo in 1817), "wealth" (Joan Robinson in 1971) and "short run business cycles" (Keynes in 1936). The model assumed: a capital/output ratio Vt; a rate of interest; Savings St; Labor (increasing at $\mathrm{N}$ ) and technical progress changing at L. Equality between St/Vt (warranted growth) ${ }^{*}$ ) and $\mathrm{Nt}+\mathrm{Lt}$ (natural one) provides the "golden age growth": everybody is employed. If $\mathrm{dYt} / \mathrm{dt}\{5\}$ equals St/Vt $\{6\}$, where Ye is (expected) income, economy is balanced. Technical progress is assumed to boost employment, but this is dubious...We saw labor-saving technologies, and new ones, to cut-down employment... $\left.{ }^{*}\right)$ This is the rate of growth of Yt, if St planned = It planned constantly. ${ }^{17}$ Ignoring recycling.

18“World Commission on Environment \& Development". "Our common future" (Pezzey \& Toman (2002)).

${ }^{19}$ Since 2005 IMO \& MARPOL convention restricted emissions from ships to specific limits. The marine oxides \& dioxides are: Sulfur (SOx), Carbon $\left(\mathrm{CO}_{2}\right)$ and Nitrogen (NOx). The EU MP Mrs. Deli K. argued that $940 \mathrm{~m}$ tons of $\mathrm{CO}_{2}$ are emitted p.a. from ships or $2.5 \%$ of global figure (October, 2020).
} 
fuel (the scrubber ${ }^{20}$ ). Christodoulou (2018) focused on the potential use of 2 new environmental indices: CSI (Clean Shipping Index) and ESI (Environmental Ship Index) for the improvement of the performance of Maritime Transport. IMO (http://www.imo.org) adopted a GHG strategy in 2018, which set ambitious indeed targets such as to halve GHG emissions from ships by $2050 /$ since 2008 and carbon intensity by $40 \%$ by 2030 /since $2008 \ldots$

Xiao et al. (2020) argued that the effort of carbon reduction is decreasing along the intensity of "fairness ${ }^{21}$ concern"-FC. Moreover, the optimal retail price, under a "revenue-sharing contract"-RSC, first decreases and then rises depending on FC intensity-FCI. On this last depends also the profit of a supply chain. If FCI is low, the RSC provides increased profit. If FCI is high, a centralized contract is more profitable. Finally, given the retailer's FC and the manufacturer's overconfidence ${ }^{22}$ attitude, the RSC provides increased profit for the first, given that FCI is high. Authors applied a mathematical and diagrammatic analysis to indicate the optimal contract selection problem given FC and manufacturer's overconfidence. FC acts negatively on carbon emissions, and the optimal carbon emission effort is high under a BC contract. The RSC is the optimal choice for a fairness-neutral manufacturer etc.

Summarizing, TLTG assumed that a global disaster will come from a global "lack of resources"23, following the classics. BTL assumed that the disaster will come rather from pollution. TLTG took into account "family planning", but it could not take into account China's allowance for a $2^{\text {nd }}$ child (2015).

\section{Part I: What Humanity Has to Sustain?}

\subsection{The Sustainable City}

Our opinion is to establish everywhere "sustainable cities"-SC. A SC is one having as an undiscussable pre-condition for those living and working in there, the elimination of the above mentioned 2-at least ${ }^{24}$-enemies. This city, smart or not, will be at least humane... A SC has to establish, we believe, a center(s) to issue sustainability certificates for existing/new products, services ${ }^{25}$, and even planned actions, in an obligatory way, following the steps of a "patent-approval office". An action is sustainable-SA, if its management, avoids the loss of life, human injury and damaging environment!

\footnotetext{
${ }^{20} \mathrm{~A}$ system to remove $\mathrm{SO}_{2}$; they are open and closed. Water is used to wash $-\mathrm{SO}_{2}$ gases-away.

${ }^{21}$ Fairness is defined as total profit average.

${ }^{22}$ This entails a belief that the knowledge of the decision-maker is more valuable than reality. i.e. as possessing a producing power and a dominant position vis-à-vis downstream retailers.

${ }^{23}$ Ricardo D (1772-1823) also assumed it. But there are now the: digital agriculture or exactfarming $\left.{ }^{*}\right)$, using drones. A. Smith too failed to vision the $1^{\text {st }}$ industrial revolution in 1760 (\& 1755-1790). $\left(^{*}\right)$ ExactFarming means the effective management of agricultural business, taking timely decisions by reducing risks. CC is going to take away $16 \%$ of agricultural production in EU by 2025 !

${ }^{24} \mathrm{We}$ wanted to investigate also immigration and terrorism, but lack of space prevented us.

${ }^{25}$ In a fire accident on "Scandinavian Star" F/B, 1990, put by a "disturbed" passenger, the fire-resistant doors between cabins closed automatically, as they should; but when doors were on fire, their material released poisonous gases, which killed the passengers! Were the doors approved for sustainability?
} 


\subsection{Sustainable Development-SD}

SD required all economies to "satisfy, not only the needs, but also the... aspirations of existing generation, without compromising the needs and aspirations of future generations" (WCED: "Brundtland Report", 1987; rephrased). SD, we believe, is an effort of a generational justice, establishing rights on existing "development means-DM": i.e. a moral claim on them, for the sake of next generations. SD holds responsible those living today (which is unfair)! DMs are means of production left over from previous generations. SD's novel element is to care, in a specific way, for all humans coming after present generation. SD theory established a "generation-depositary", acting on behalf of next generations, we reckon!

It is fair, we believe, the present generation to care about only the next one, and the next one for the next one, and so on. When economists talk about DM, they mean products of manufacturing and craft industry. We understand that $\mathrm{DM}^{26}$ delivered to present generation by the previous one, must be used with precaution, and wisdom, and in a such manner so that to be delivered intact, or even in a higher quantity, to next generation... This is apparently in the area of utopia, if humans are greedy and selfish! Epicureans (c. 300 BC) said: "Let us eat and drink... tomorrow we die"! A number of persons believe this even today. SD presupposes that DM are exhaustible, depending on use... SD thus is a warning. From the discussion so far, we understand that the bases of SD are sentimental, moral and depend on the love one feels for one's children.

Environmentalists observed that when a resource is used repeatedly in a high degree (over-exploited), and a product is over-produced, they reach extinction. Certain fish-types are best examples. However, 4 so far industrial revolutions did not prove that the depletion is true, though we saw some kinds of fish ${ }^{27}$, animals, birds, plants etc. to disappear, or to become rare (in the state of extinction, as we say). Also, we saw beaches to lose their original color, after the invasions of millions of tourists (massive tourism). We saw also animals to die from lack of water etc. and people to immigrate. Managing environment is obviously required!

There is a less accurate knowledge-as always used to be, but improving-about the real existing quantity of DMs, like: oil, gas, other minerals, etc., below earth's surface ${ }^{28}$, under sea's bottom ${ }^{29}$, and $\ldots$ even on near-by planets ${ }^{30}$ !

\footnotetext{
${ }^{26}$ Ancient Greeks said: "take measures, if you want to do a perfect job".

${ }^{27}$ Fishers know that parent-fishes have to be allowed to bear little fishes before captured. Small fishes have to grow before captured too. EU legislation with surveillances made this clear.

${ }^{28} \mathrm{New}$ sources of oil \& gas discovered worldwide after 1974 \& 1979 oil crises (e.g. North Sea; Alaska etc.). Schist also appeared! E.g. clean electric power can be produced by sea waves ("World Council for Energy", 2020, Athens). Greece e.g. can produce 208 MWh p.a. from sea depths of 100m \& $2 \mathrm{~km}$ from coast. More mature are the "wind parks" \& "wind turbines". 175 wind turbines inside sea can provide electricity in $1 / 2 \mathrm{~m}$ houses (case: Kent area, UK).

${ }^{29}$ North-Sea-oil made Norway a rich country, and saved English pound. Greece and Cyprus search for oil and gas in Aegean Sea. This made Turkey jealous, and aggressive, especially for Cretan deposits, estimated by Turks as enough to supply Turkey for about 570 years...

${ }^{30}$ Moon can provide... water (NASA 2020).
} 
Moreover, a new science developed, since 1982, following "Law of Sea" (UNCLOS II): "Marine Economics" dealing with... sea economy ${ }^{31}$. Worth noting is that sea economies cover $2 / 3$ of the Globe! Thus, the depletion-danger went further away, since 1982, but pollution arrived stronger, and it meant to stay...!

\subsection{Humanitarian Concerns in a SC}

Normative economics had to care about people, if their income is zero, we believe. Surplus products, excess food, products and medicines near expiry, defective items, excess clothing etc., why not be given free to persons in-need in the "(open) markets"? After writing the above, we read (01/11/2020) that a Greek "bank" established in 2015 under the name of "humanitarian bank", and did exactly the above, by providing shelter to 270 citizens and food to $1 \mathrm{~m}$, among other things.

Science invents new materials ${ }^{32}$, fuels, and technologies, and has speeded-up production... People increased its dependence ${ }^{33}$ : on alcohol, smoking, drugs, etc. More products (paints, products, etc.) are produced ecologically, but their prices are high to be able to replace the non-ecological ones. Emphasis here is required to be put by all societies.

Summarizing, societies, we believe, need to establish from now on, a number of "sustainable cities", focusing exclusively on "sustainable citizen". We do not foresee a possible lack of DM. The obvious enemy, which economies have to win, is CC. CC is the "situation where climate kills its citizens, from time to time, due to weather's revenge".

\section{Part II: COVID-19's Indirect (Positive) Impacts on Global Economy/Greece (Table 1)}

The measures taken for COVID-19 in a global scale was, in fact, an experiment, which provided valuable data. We know now the effect on environment of: restricted outdoor activities; lockdowns; less driving; limited visits; less use of air transport, limited tourism, fewer: marriages, parties, group entertainment, cruises, baptisms... and social gatherings. We know now what we should retain, in a very careful way, from the painful COVID-19 period... if it ends.

COVID-19 obliged societies to proceed immediately to more ... computerization, digitalization, so that citizens to do things only from a distance! In Greece, 50 interviewed CEOs agreed, in March, 2020, that COVID-19 speeded-up Governmental digitalization (BHMA magazine).

\footnotetext{
31"Marine Affairs". Sea's economy deals with the exploitation etc. of sea resources beyond one's territorial waters and within its $\mathrm{AOZ}$ and continental shelf.

${ }^{32}$ E.g. nylon!

${ }^{33}$ The number of existing gyms, suspended by Covid-19, rose before 2019; also, the number of doctors dealing with nutrition; dieticians; manufacturers of food supplements and vitamins, etc. People prefer less calories-food, more vitamins \& less or no sugar. Human versatility is remarkable: we have now in-house dining or fine dining (Greece Oct. 2020) by delivery-services for wealthy customers up to 6 persons ...!
} 
Table 1. Benefits derived, indirectly, by COVID-19 (2020-2021).

\begin{tabular}{|c|c|c|c|}
\hline $\begin{array}{l}\text { Reduction in oil production } \\
\text { (up to } 30 \% \text { ); improved } \\
\text { environment, cutting } 8 \% \text { p.a. } \\
\text { the demand for energy } \\
\text { (i.e. } 1.93 \text { million less barrels } \\
\quad \text { of oil }{ }^{34} \text { (June 2020) }\end{array}$ & $\begin{array}{l}\text { It valued-up (in S\&P 500) } \\
\text { technology companies: } \\
\text { Microsoft }^{35} 19 \% \text {; Apple 18\%; } \\
\text { also, Amazon } \sim 14 \% \text {; Google } \sim 13 \% \text {; } \\
\text { Facebook ( 7\%) (= 71\%); plus, } \\
\text { an investment company; Visa; } \\
\text { JPMorgan; Johnson \& Johnson, } \\
\text { Walmart, Salesforce (Cloud); } \\
\text { Amgen (biotechnological industry) } \\
\text { \& Honeywell (manufacturer) }\end{array}$ & $\begin{array}{l}\text { Increased: the sales of PCs, } \\
\text { means of tele-conferences; } \\
\text { skypes; videos; e-mails; } \\
\text { postal services \& couriers; } \\
\text { \& take away services }\end{array}$ & $\begin{array}{l}\text { Increased: electronic purchases } \\
\text { via internet plus credit cards } \\
(+60 \%) \text {; food deliveries via } \\
\text { internet; Mask production; } \\
\text { admissions in private hospitals; } \\
\text { needs for specific medical } \\
\text { management }\end{array}$ \\
\hline $\begin{array}{l}\text { Intensified: phone banking }\left(^{*}\right) \text {; } \\
\text { Internet banking }\left({ }^{* *}\right) \& \text { mobile } \\
\text { banking }\left({ }^{* *}\right) ;\left(^{*}\right) € 16 \text { b spent in } \\
\text { first } 6 \text { months }(2020) \text { in Greece } \\
(+13.4 \% \text { since } 2019) \& € 1 \text { b by } \\
\text { tourists }(-63 \%) \text {, by credit cards; } \\
\text { helped by the system of no-pin } \\
\& \text { an increased } € 50 \text { limit }\end{array}$ & $\begin{array}{l}\text { Cargo air transport } \\
\text { increased } 30 \%\end{array}$ & $\begin{array}{l}\text { Increased demand for burial } \\
\text { grounds \& funeral services... }\end{array}$ & $\begin{array}{l}\text { Increased: the number \& the } \\
\text { activity of: barbers; hair dressers; } \\
\text { nail caring; the demand of personal } \\
\text { hygiene products; beauty products } \\
\text { +14\%; mini markets sales; home } \\
\text { cleaning products (+21.2\%) } \\
\text { (Greece); sales of bicycles, } \\
\text { electric cars }{ }^{36} \text {, and other } \\
\text { electric transport means }\end{array}$ \\
\hline $\begin{array}{l}\text { Rapid resort of Greek state to } \\
\text { digitalization (since March 2020) }\end{array}$ & $\begin{array}{c}\text { Wake-up of global millionaires } \\
\text { (Soros, Gates, Buffet) proposing } \\
\text { to pay increased taxes (IMF) } \\
(18 / 10 / 2020) ! \\
\text { EU suspended austerity } \\
\text { programs }\end{array}$ & $\begin{array}{l}\text { Reduced pollution; increased } \\
\text { investments in renewable sources } \\
\text { of energy }{ }^{37} \text {; closure of lignite } \\
\text { production by } 2023 \text { (Greece); } \\
\text { reduction in electricity cost; } \\
\text { Electricity in Greece costs } € 51 / \mathrm{MHh} \\
\text { (wholesale price), more than double } \\
\text { that of Germany (€23) (June 2020)! } \\
\text { Greece delayed to follow the "target } \\
\text { model }{ }^{38 "} \text { of EU. Nuclear power was } \\
\text { out of question due to } \\
\text { country's...earthquake sensitivity... }\end{array}$ & $\begin{array}{c}\text { Increased use of Cloud }{ }^{39} \\
\text { construction of data centers } \\
\text { (Greece); Amazon established a } \\
\text { web services center; increased } \\
\text { digital immigrants; + optical } \\
\text { fibers }(11 / 10 / 2020) \text {; thousands } \\
\text { of rapid etc. tests for COVID-19; } \\
\text { intensity in producing batteries } \\
\text { (European battery alliance) }\end{array}$ \\
\hline $\begin{array}{l}\text { It pushed societies (Greece) } \\
\text { towards more computerization, } \\
\text { \& digitalization! In } 3 \text { years, } \\
\text { Greek citizens will make all } \\
\text { their contacts with the } \\
\text { State via internet... }\end{array}$ & $\begin{array}{l}\left.{ }^{*}\right) \text { Banking transactions }(90 \%) \\
\text { made through electronic networks: } \\
\text { "ATMs", APS-“Automatic } \\
\text { Payments System", "internet" \& } \\
\text { "mobile" in } 2020 \text { ( } 1^{\text {st }} \text { sem.; Greece); } \\
\text { the number of bank-branches in } \\
\text { Greece reduced by } 2263 \text { between } \\
2010 \text { and } 2019 \text { from } 4097, \\
\text { not due only to COVID- } 19 !\end{array}$ & $\begin{array}{c}\left({ }^{\star *}\right) \text { Transactions valued } \\
€ 136.4 \mathrm{~b}(+5 \% \text { since } 2019, \\
\left.1^{\text {st }} \text { sem. }\right)(\text { Greece })\end{array}$ & $\begin{array}{l}\left({ }^{* *}\right) \text { Transactions valued } € 6.9 \mathrm{~b} \\
\left(2020,1^{\text {st }} \text { semester }\right)(+53 \% \text { since } \\
\left.2019,1^{\text {st }} \text { sem. }\right) \text { ! In Greece } 2.7 \mathrm{~m} \text { users } \\
\text { emerged, }\left(1^{\text {st }} \text { sem. } 2020\right), \\
(27 \% \text { of total population }) \text {, and } \\
1 \mathrm{~m} \text { plus in } 6 \text { months! Credit } \\
\text { cards are in close cooperation } \\
\text { with mobile phones }\end{array}$ \\
\hline
\end{tabular}

Source: various articles in weekly newspapers \& magazines covering the first 9 months of 2020.

${ }^{34}$ Produced by OPEC+ (source: Norwegian class.). "OPEC+" obtained 10 additional members (total 23); OPEC (1960) had 5 main original members-Governments: S Arabia, Iran, Iraq, Kuwait \& Venezuela. OPEC+ produces $1 / 2$ of global oil production of about $70 \mathrm{~m}$ barrels $\mathrm{p} / \mathrm{d}$ (at $\$ 40$ per barrel). Russia became a member too.

${ }^{35}$ In Feb. 2020 held the $1^{\text {st }}$ position in S\&P500 with $\sim$ \$1.43tr capitalization.

${ }^{36}$ In Germany about 137,000 electric cars exist in 2020 against about 2000 in 2006, \& 1 m by $2022 \ldots$ By $203028 \%$ of all cars will be electric in Germany, $29 \%$ in Europe and USA, \& 38\% in China. Germany subsidizes electric cars by $€ 6000$.

37 “Akuo Energy Greece" spends $€ 1 b$ for renewable sources of energy in 5 years using: photovoltaic panels, similar aesthetic tiles/roofs on land \& in sea; wind parks; $1 \mathrm{GW}$ at $€ 14 / \mathrm{MW}$; energy storage (source: Conference by "Hellenic assoc. for energy economics", Oct. 2020, Athens).

${ }^{38}$ In operation in Greece (01/11/20). EU is estimated to save $€ 1 \mathrm{~b}$ p.a. by opening electricity market to all suppliers \& from outside EU borders. The model will establish electricity markets from which a nation can buy electricity in 3 different occasions (intraday etc.) as well forward.

${ }^{39}$ Cloud brought... a "rain" of 14 investments in Greece of $€ 1.8 \mathrm{~b}$. Microsoft spends $€ 1 \mathrm{~b}$. Certain others $(€ 386 \mathrm{~m})$ focus on producing energy from Sun. The benefit in Greece from digital state will be $€ 50 \mathrm{~b}$. A $2^{\text {nd }}$ data center G-cloud needs about $€ 24 \mathrm{~m}$. The number of logins were about $59 \mathrm{~m}$ for Jan.-Sept. 2020 in Greece (15/10/2020). 
An historian, (during “Athens Democracy Forum”, Athens, Oct. 2020), mentioned that the coming ... global war will be on...data! In other words, societies enter into the dynasty of the algorithms, using artificially intelligent machines! Everybody's personal data will be known!

"Parachuters" fell from Greek sky on land of Salonica: "Pfizer" and "Cisco" establishing innovation centers on line; "IBM” (Infosys Finance); “Think Silicon of Applied Materials”; Microsoft (SoftoMotive: making robots); \& Google. Greece entered ${ }^{40}$ into the "Clean Network/5G clean path". Automated cars; clever tele-managed domestic devices; and effective crucial infrastructures are coming. Saving time by using clever machines, will allow us to copy Ancient Greeks, where Masters used slaves, and Masters promoted... philosophy. But slaves were real ones...Will machines be slaves or masters?

Turing A. (1912-1954) - an English mathematician etc.-is the father of computers. He was in charge of the multi-scientific team to un-crypt (1936) the German cryptographic machine "Enigma"! Important is that the machine time required, for revealing German code, which was changing every morning, was... 20 years. More important is that in 2017 the "Imperial War Museum" using: artificial intelligence, modern computers and programmers, broke "Enigma" code in 13 minutes... If time is money, computers brought-in so much! But this is not written down...

Greece established a Ministry of Digital Governance, and passed ${ }^{41}$ a law, (a code), (end-Sept. 2020), concerning country's transition to digitalization and 5G. Greece tries to copy Estonia in state electronics as many say... The target is to provide $5 \mathrm{G}$ to over $50 \%$ of Greek population by 2021 ; in line with the "Greek Organization of Telecommunications"-OTE, (using Eriksson's technology)... and with EU legislation.

The higher speed of transmission needs, however, safe data! $5 \mathrm{G}$ is 10 times faster than 4G (RAN compared with Core \& open RAN). Globally, 5 companies pursue 5G: Huawei, ZTE, Samsung, Eriksson \& Nokia. EU suggests to member-countries, for $5 \mathrm{G}$, to prefer EU providers, but not excluding China...

\section{Part III: COVID-19's Indirect (Negative) Impacts on Global Economy/Greece (Table 2)}

\section{COVID-19's Impact on Sea Transport}

Shipping industry worth of about $\$ 500 \mathrm{~b}$ (the 9 top global fleets only) (end-April $2020)^{42}$, established an entire sector, mainly private, organized to transport oil and oil products over 120 years now. We mean tankers and oil-product carriers. Subsequently, LPG (liquefied petroleum gas; 1964) and LNG (liquefied natural gas; 1959; and mainly in 1970s) carriers (Stopford, 2009: p. 484) emerged.

\footnotetext{
${ }^{40}$ Chinese reported that "Huawei" provides network services to more than $3 \mathrm{~b}$ persons over 170 countries ("Dialogue for digital co-operation between China and EU”, Sept. 2020)!

${ }^{41}$ Providers of radio-frequencies from $700 \mathrm{MHz}, 2 \mathrm{GHz}, 3.400-3.800 \mathrm{MHz}$ and $26 \mathrm{GHz}$, costing $\sim € 367 \mathrm{~m}$, are needed.

${ }^{42}$ Source: Vessels Values.
} 
Table 2. The harmful effects of COVID-19, 2020-21.

\begin{tabular}{|c|c|c|c|}
\hline $\begin{array}{c}\text { In } 8 \text { months ( } 2020) \text {, air } \\
\text { passenger-kms fell by } 80 \% \\
\text { (since 2019) \& revenue by } 95 \% \text { for } \\
11 \text { EU companies ( } 2^{\text {nd }} \text { quarter } 2020 \text { ) } \\
\text { source: IATA); } 4 \text { EU airlines lost } \\
€ 12.2 \mathrm{~b} \text { in } 6 \text { months (2020); industry } \\
\text { reduced its working posts by } \\
900,000 \text { (Feb.-Sept. 2020); touristic } \\
\text { period shrunk to } 40 \text { days ( } 2020) \\
\text { for airlines; Airplanes became ... } \\
\text { restaurants \& bars on earth...\&... } \\
\text { deliver (airplane) food... to homes } \\
\text { (Singapore) (Oct. 2020) (source: } \\
\text { IATA). }\end{array}$ & $\begin{array}{l}\text { Car manufacturers lost } \\
20 \% \text { of their } 2019 \text { demand }\end{array}$ & $\begin{array}{l}\text { It led people to hoard }{ }^{43}(2020) \text {; } \\
\text { exhibitions \& conferences } \\
\text { suspended; Germany used to } \\
\text { attract } 410 \mathrm{~m} \text { visitors p.a. } 2^{\text {nd }} \\
\text { in globe (after USA); up to } 180 \\
\text { national \& international } \\
\text { exhibitions with } € 14.5 \mathrm{~b} \\
\text { worth of business }\end{array}$ & $\begin{array}{l}\text { Reduced seaborne trade by } 1 \mathrm{~b} \\
\text { tons according to Clarkson's, or } \\
\text { about } 11 \% \text { (May 2020); about } 6 \% \\
\text { is expected for } 2020 \ldots \text { Seaborne } \\
\text { trade was over } 9 \mathrm{~b} \text { tons in } 2019 ; \\
\text { other estimations stated that trade } \\
\text { rose about } 5 \% \text { in July, while EU } \\
\text { achieved } 6 \% \text { rise in its exports \& } \\
4 \% \text { in its imports; USA achieved } \\
11 \% \text { in both; China achieved } 9.5 \% \\
\text { rise in its exports... (internet); } \\
\text { WTO estimated trade to fall by } \\
\left.9.2 \% \text {; } 14.3 \% \text { less trade (2020 } 2^{\text {nd }} \mathrm{q} .\right) \text {; } \\
\text { Europe }-24 \% \text { in exports and } \\
\sim-22 \% \text { in N. America }\end{array}$ \\
\hline $\begin{array}{l}\text { Reduced global population by } \\
1.5 \text { m; \& those recovered from } \\
\text { COVID-19 may not be free from } \\
\text { further complications }\end{array}$ & $\begin{array}{l}\text { Reduced demand for oil due to } \\
\text { lock-downs; excess oil stored } \\
\text { urgently in tankers, among others; } \\
\text { a price-war between S. Arabia \& } \\
\text { Russia led to excess production; this } \\
\text { led oil prices down (Spring 2020); } \\
\text { the price of oil from Schist also } \\
\text { dropped; Exxon exited the S\&P } \\
500 \text { (end-August 2020), \& from } \\
\text { Dow Jones, while in } 2009 \text { held } \\
\text { the } 1^{\text {st }} \text { position in capitalization ( } 12^{\text {th }} \\
\text { in 2019), followed by } \\
\text { Chevron in the } 11^{\text {th }} \text { position }\end{array}$ & $\begin{array}{l}\text { Reduced investments by tourist } \\
\text { industry; tourism in Greece used } \\
\text { to provide } 20 \% \text { of GDP and to } \\
\text { serve } 30 \mathrm{~m} \text { tourists (2019) against } \\
6 \mathrm{~m} \text { estimated (2020); all athletic } \\
\text { endeavors suspended \& Olympic } \\
\text { Games in Tokyo for } 2020 \\
\text { postponed; }\end{array}$ & $\begin{array}{l}\text { Retail sales fell by } 27 \% \text { - } 30 \% \text { in } \\
7 \text { months (2020) in Greece; } \\
\text { less } € 25 \text { b; big super markets lost } \\
50 \% \text { of their sales; less sales in cash } \\
\text { \& carry by } 9.5 \% \text { (Feb.-May 2020); } \\
\text { restaurants, taverns, bars, hotels } \\
\text { remained closed or had reduced } \\
\text { hours, allowing distances between } \\
\text { tables; cinemas, theaters, parades } \\
\text { etc. were suspended in March and } \\
\text { Nov. } 2020\end{array}$ \\
\hline $\begin{array}{l}\text { Fall in GDP in } 22 \text { economies }{ }^{44} \\
\text { from } 1 \% \text { (Taiwan) to } 13 \% \\
\text { (Philippines) from } 2019 \text { to } \\
2025 \text { (IMF); USA GDP }-30 \% \text {; } \\
\text { EU }-4.4 \% \text { (World Bank); } \\
6 \text { m people at the poverty limit }\end{array}$ & $\begin{array}{l}\text { Women and low - paid - workers } \\
\text { working in services hit more hardly } \\
\text { in USA (Fed. Res.); } 20 \text { m lost their } \\
\text { jobs; 8\% unemployment }\end{array}$ & $\begin{array}{l}\text { Global economies spent } \$ 12 \text { tr. } \\
\text { for the Pandemic (IMF); } \\
\text { rise in the demand of } \\
\text { pharmaceutical \& } \\
\text { medical supplies }\end{array}$ & $\begin{array}{l}\text { In USA: } 38,000 \text { hotels closed-up } \\
\text { (11/10/2020); } 850,000 \text { small firms } \\
\text { closed (Womply platform.); } \\
\text { 1.6 m hotel personnel unemployed; } \\
36,000 \text { chain-shops will be closed } \\
\text { (like gyms, face beauty institutions, } \\
\text { etc.); } 216,000 \text { less civil } \\
\text { servants (USA) }\end{array}$ \\
\hline
\end{tabular}

Source: as in previous table.

International sea transport was seeking a "green" fuel. Recently, there are... 16 fuels already in the market, including ammonia, hydrogen, bioethanol etc., and 10 relevant technical systems ${ }^{45}$. Shipping also considers... building electric ships and ships producing zero-emissions! It immediately built ice-breakers and ships ice-strengthened to serve Antarctic.

${ }^{43} \mathrm{GFC}$ led people to hoard, given capital controls. The amount hoarded was equal to the difference between people' money in bank deposits before capital controls and after. For Greece this was $€ 20$ billion out of $€ 40 \mathrm{~b}$.

${ }^{44}$ The GDP in Eurozone will be reduced from $0.5 \%$ for Lithuania to $11 \%$ for Spain. Greece will have a $-8 \%-9 \%$ as Eurozone. Italy-8.5\%; France $-10 \%$; Germany near -6\%. Source: $E C B, 01 / 11 / 2020$. The November, 2020, lockdowns are expected to increase these negative growth rates of the GDP.

${ }^{45} \mathrm{~A}$ competition among fuel manufacturers! Some argue that more than 500 LNG carriers use LNG as fuel, out of 27,700 ships globally. Given the 2020 "global Sulphur Cap" and the " $\mathrm{CO}_{2}$ emissions-cutting-off". 
Ship crews suffered from COVID-19, given that 25 persons, on average, work together at close distances, (using masks only in ports), and are obliged to reach ports in quarantine for loading/unloading, repairs or repatriations! Many crews locked-out of their family for 7 months or so.

Worth noting is the case of cruising ships! Recent the "Main Shift 6" CS, in Sept. 2020, cruising in Cretan waters, manned by 766, of which 12 found positive to virus in the $1^{\text {st }}$ test, but not in the $2^{\text {nd }} \ldots$ Crew looked after 922 passengers. The famous "Queen Mary" in California and "Queen Elizabeth 2" in Dubai (since 2018) are sea hotels with 228 rooms and 13 restaurants... Inspections from classes etc. will be done from a distance, aided by drones.

\section{Part IV: The Climate Collapse in Globe, EU and Greece}

\subsection{Global Cyclones}

Threats to people we had from climate, appearing mainly in the form of faster coming tropical cyclones (hurricanes; storms etc.) (Graph 1) and of fires and floods all over the world, and par excellence in USA.

As shown, tropical cyclones are of 8 types (at least). "Cyclone" means the

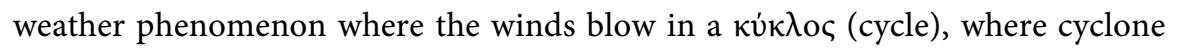
runs round a hole: the "eye". People in USA experienced hurricane Catrina ${ }^{46}$ in 2005 ! Almost $1 / 2$ a million deaths caused by the 24 major "climatic attacks" from 1780 to 2020 (Appendix 1). Notable is that till 1932, there were only 21 cyclones, but many more thereafter! Moreover, billions of dollars cost thousands of collapsed houses and damaged private cars, apart from the destruction of infrastructure! We counted almost $\$ 500$ billion damages due only to 10 Atlantic Ocean hurricanes (source: internet).

\subsection{Cyclone "Janus": The Case of GREECE (Sept. 2020)}

Greece resembles more... Egypt than its past self, obtaining deserts, lacking water at times, and planting rows of tropical trees. Date-palms e.g. are more suitable since some time in Greece, and planted in Athens since 2004, (on the occasion of Olympic Games), replacing poplar- and plane-trees.

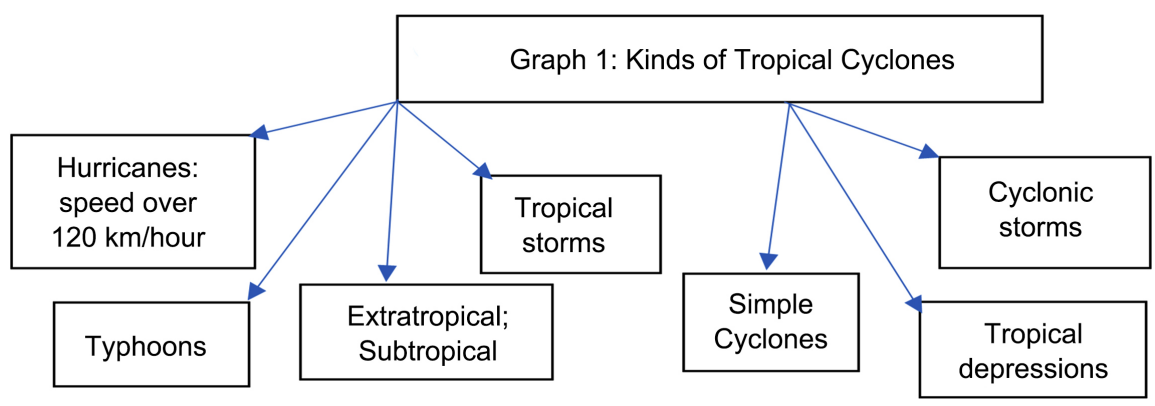

Graph 1. Kinds of tropical cyclones. Source: author and Internet.

\footnotetext{
${ }^{46}$ Bush administration spend $\$ 105$ billion for repairs \& reconstructions; "Katrina" smashed-down 30 oil-platforms; closed-out 9 refineries! Followed by hurricanes Sally, Laura etc. Scientists counted 1616 tropical cyclones \& 926 hurricanes so far... (internet).
} 
Greece, in Sept. 2020, hit, for the $1^{\text {st }}$ time, by the cyclone "Janus", with 4 - 5 dead. This caused rivers to jump over their bounds, forced by more than regular rain-water and violent winds. Janus brought over tons of mud, and hundreds of stones, burying entire cars... Fast winds dislocated and carried-away all removable objects, panels, cut-down electric poles etc., got-out trees, took-away fences, destroyed cultivations, eliminated animals, etc., smashed-down bridges, shallowed roads, and took - roofs - away.

"Stealing" from rivers part of their land, so that to build houses there, a time comes for rivers, using their increased, by heavy rain, waters, to claim their land back, not at all gently! Greek residents in the cities and villages deprived for days of electric power, water and cell phones, or phones, at the time they were most needed! Electricity poles, due to thunderbolts, burnt-out, or dropped-down by trees falling on them...

\subsection{Cyclones' Impact Globally}

Over 200 years of tropical cyclones brought-in 1.9 million dead ${ }^{47} \ldots$ In addition, tropical cyclones in sea created large waves, heavy rains, floods and high winds, disrupting international sea transport and occasionally creating shipwrecks.

As shown in appendix 1, $24+3$ main hurricanes and storms are recorded since 1780. Deaths due to them exceeded 453,000. Their damages cost $\$ 345$ billion... Since 1995 the annual number of cyclones in Atlantic Ocean is estimated as $87 \pm 10$ (internet sources). But the intensity, speed and duration of hurricanes increased since 1995 (US National Oceanic \& Atmospheric Administration's national hurricane center, 2019)... due to climatic change...

Two million acres of woods destroyed in California - again - in 2020... Five hundred billion dollars p.a. (65\% from private sector) are estimated to be needed to reverse USA's present course towards zero pollution by $2050^{48}$.

Humanity had a chance, at the turn of the previous century, when engines constructed based on oil, while there were other alternatives (Arthur, 1994)! Surely this was rather early! Now is, however, rather late!

\subsection{EU Policy to Stop CC}

Commendable is the recent decision of the President of EU Commission, Mrs. Ursula von der Leyen, to protect EU environment. Consequently, German car manufacturers have to stop, at once, producing traditional car engines! We believe $e^{49}$ that EU is firmly determined to upgrade EU environmental protection policy, and speed it-up this time.

\footnotetext{
${ }^{47}$ Wikipedia, down/ed 21/09/2020.

${ }^{48}$ Weekly journal "Kathimerini", 20/09/2020, p. 23.

${ }^{49} \mathrm{EC}$ submitted a law proposal, voted by a great majority, revising the EU system of monitoring, counting-down \& verifying $\mathrm{CO}_{2}$ emissions from international maritime transport. EC is pressing shipowners towards IMO's requirements for ships of 5000 GT and over. EC said that there is no clear landscape for knowing for sure how much shipping pollutes air with $\mathrm{CO}_{2}$ emissions! It is true that shipping industry argues that shipping pollutes less vis-à-vis e.g. air industry, \& dislikes measures increasing its operating cost.
} 
She, in an action under the proverb, we reckon, "better late than never", announced $^{50}$, in her speech in European Parliament, the issue of $€ 750$ billion of "Green Bonds" to finance an EU "green growth". Creating also a hope for reducing gases to the atmosphere of Europe. Can one stone kill two birds? Growth and CC? Our world obviously built on a wrong assumption: abundant, cheap and friendly to environment, fuel: i.e. oil. But oil since 1973 is no more abundant or cheap ${ }^{51}$ or friendly ... The new EU plan aims at achieving an increased \%, i.e. $55 \%$ reduction of pollution, (against previous $40 \%$ ), up to 2030 (in EU), comparatively with the 1990 levels.

The EU climatic policy caused the immediate reaction of "European Union of Car Manufacturers" (ACEA), and especially that of... German car manufactures, who also called to stop immediately producing traditional car engines, and to reduce releases of $\mathrm{CO}_{2}$ by $1 / 2$ by 2021 ! A clear "push" is towards electric cars etc., where, however, USA car manufacturers ${ }^{52}$ seem to be more competitive... USA car manufacturers plan to spend $\$ 300 \mathrm{~b}$ to prepare electric cars between 2025 and 2030.

The Green EU policy can be summarized in Table 3.

We all know that CC is accomplished eventually at an increasing momentum as time elapses, but a global unanimous front is still lacking, despite Kyoto and Paris summits! Who was more sensitive in avoiding climatic destruction worldwide (Table 4), judging by the funds devoted?

As shown, the funds devoted for sustainable investments, since 2012, increased by 2.3 times, reaching $\$ 31$ trillion in 2018. EU is a pioneer with a $46 \%$ share, followed by USA (39\%).

The $27 \mathrm{EU}$ ministries of environment agreed in $23^{\mathrm{rd}} / 10 / 20$ in Luxembourg for the complete and final elimination of $\mathrm{CO}_{2}$ emissions (except Bulgaria). This on top of the "R\&RF-Recovery \& Resilience Facility", devoting funds from an EU budget for 2021-2027 of €1,074tr. EU means business on environment. In the case of shipping, EU was determined to "push" $\mathrm{IMO}^{53}$ so that international shipping to enter into the "EU emissions trading system"-EU-ETS. The final aim of $\mathrm{EU}$ is to reduce immediately $\mathrm{CO}_{2}$ emissions from large ships.

\subsection{Our Model of an Optimal Treatment of the Environment}

Ten top firms in USA achieved ${ }^{54}$ (in 2018) a revenue of $\$ 182 \mathrm{~b}$, of which $\$ 71 \mathrm{~b}$ was the value of emitted greenhouse gases (Scan 1)! So, if above firms were obliged to cut down emissions, they would have to abandon $39 \%$ of their revenue... In fact, state subsidized those firms, as it spent $\$ 67 \mathrm{~b}$ for the health of above companies' employees!

\footnotetext{
${ }^{50}$ EU Commission, Plan for Clean Growth (2020)", with a view to mobilize funds for a "Recovery Fund" issuing Green bonds of $€ 750 \mathrm{~b}$.

${ }^{51}$ Time when oil became 5 - 6 times dearer for the first time.

${ }^{52}$ Electric; saving almost $7 \mathrm{kgs}$ of $\mathrm{CO}_{2}$.

${ }^{53}$ The International maritime organization-IMO (1982) (IMCO till 1958) is an UN organization with $\sim 150$ nations-members to decide on important matters of international sea transport. Greek shipowners maintain a high esteem for IMO.

${ }^{54}$ Harvard Business School research run by Prof. Seraphim G, 18/10/2020, in weekly newspaper

"Kathimerini".
} 


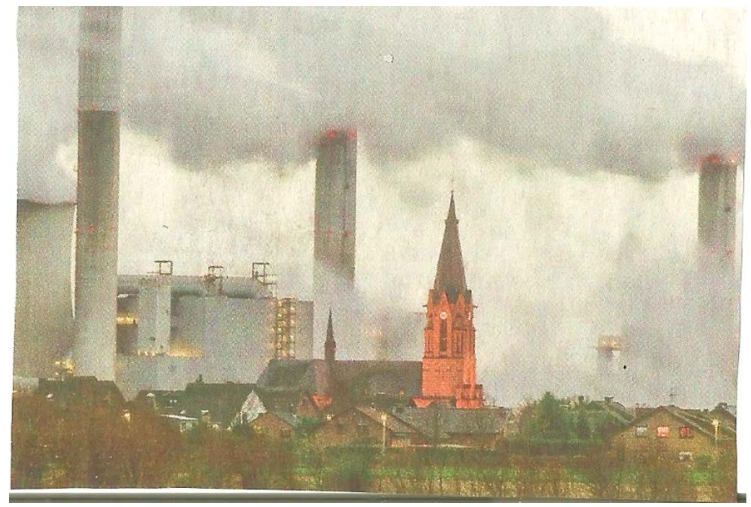

Scan 1. Can Profits and Pollution "produce" together? Source: Reuters; modified.

Table 3. EU policy to prevent EU climatic collapse.

\begin{tabular}{ccc}
\hline Actions 1 - 2 & Actions 3 - 4 & Action 5 \\
\hline $\begin{array}{c}\text { Adoption of clean energy technologies, } \\
\text { especially in: mass transport, stations of } \\
\text { electric supply; cars to use hydrogen }\end{array}$ & $\begin{array}{c}\text { Faster development } \\
\text { \& use of renewable } \\
\text { energy sources }\end{array}$ & $\begin{array}{c}\text { Initiating innovations in } \\
\text { saving energy, especially in } \\
\text { public \& private buildings }\end{array}$ \\
$\begin{array}{c}\text { Speed-up broadband services \& 5th } \\
\text { generation networks; (antagonism } \\
\text { appeared between USA and China over } \\
\text { 5G networks \& relevant technologies) }\end{array}$ & $\begin{array}{c}\text { End of production of } \\
\text { traditional car engines } \\
\text { based on oil }\end{array}$ & \\
\hline
\end{tabular}

Source: EU Commission policy “Europe’s next generation”, 2020.

Table 4. Amounts spent for Green sustainable investments worldwide, 2012 and 2018.

\begin{tabular}{ccccc}
\hline Nation or economic union & \multicolumn{2}{c}{$\begin{array}{c}\text { Value of Green investments } \\
2012 \text { (in trillion \$) \% rounded }\end{array}$} & \multicolumn{2}{c}{$\begin{array}{c}\text { Value of Green investments } \\
2018 \text { (in trillion \$) \% rounded }\end{array}$} \\
\hline EU & 8.8 & 66 & 14.1 & 46 \\
USA & 3.7 & 28 & 12.0 & 39 \\
Canada & 0.6 & 4.5 & 2.2 & 7.2 \\
Australia \& N Zealand & 0.2 & 1.5 & 1.7 & 5.54 \\
Japan & 0.01 & 0.1 & 0.7 & 2.3 \\
Total & $\sim 13.3$ & $\sim 100$ & $\sim 31.0$ & $\sim 100$
\end{tabular}

We assume that: 1) In order to prevent CC, we will depend exclusively on global production-private or state ${ }^{55}$; 2) Production to be done with 5 factors: Qi $=\mathrm{f}(\mathrm{Ci}, \mathrm{Wi}, \mathrm{Li}, \mathrm{Si}, \mathrm{Ei})\{1\}$, where $\mathrm{Qi}$ is the production of the $\mathrm{i}_{\mathrm{th}}$ firm, using inputs from $\mathrm{C}, \mathrm{W}, \mathrm{L}, \mathrm{S}$ and $\mathrm{E}$, i.e. capital, labor, land, ... sea, and... environment. 3) Technical efficiency is pre-supposed (microeconomic theory). As shown, Sea is a factor of production after 1982 "law of sea". Our innovation is also to insert... environment into the production function!

${ }^{55}$ Matters of consumption (utility, welfare, maximization etc.) are ignored, because consumers will be supplied with clean products, if production is clean. 
If Equation $\{1\}$ has to get a specified form, then a Cobb-Douglas function, as simpler, or a CES one can be used. All inputs are essential, though sea may not enter into all productions. (4) There are no exhaustible resources. Even non-renewable resources, when finished, can be replaced by others (e.g. oil by schist and gas; dirty diesel electricity by clean, and so on). Maximizing $\{2\}$ will be subject to cost minimization: $\mathrm{C}=\mathrm{C} 1 \mathrm{P} 1+\mathrm{W} 2 \mathrm{P} 2+\mathrm{L} 3 \mathrm{P} 3+\mathrm{S} 4 \mathrm{P} 4+\mathrm{E} 5 \mathrm{P} 5+\mathrm{fc})\{3\}$; and adding $\lambda\left[\mathrm{Q}^{0}-(\mathrm{AC} 1 \mathrm{~W} 1 \mathrm{~L} 1 \mathrm{~S} 1 \mathrm{E} 1)\right]\{4\}$, where P1-5 are the prices of the factors of production, $\mathrm{fc}$ is fixed cost, $\lambda$ is a (positive) Langrage's multiplier $(\lambda=\mathrm{dQ} / \mathrm{dC}$ $=0\{5\}$ ). Equations $\{3\}$ and $\{4\}$ have to be put equal to zero for cost minimization. Production is taken to be at a prescribed level $\left(\mathrm{Q}^{0}\right)$. Deriving only one partial derivative from six, we get: $\mathrm{dC} / \mathrm{dE}=\mathrm{P} 5-\lambda \mathrm{F} 5=0\{6\}$, where $\mathrm{F} 5=\mathrm{P} 5 / \lambda\{7\}$, which means to set the marginal product of environment ${ }^{56}$ equal to its price (divided by $\lambda$ ).

We need prices for Sea and Environment. The Sea up to AOZ "belongs" to coastal state, and thus if a company exploits it and pays fees to the state, this will be the price of sea (e.g. license fee for fish-farming; aqua culture etc.). The price ${ }^{57}$ of environment... is the value of a unit quantity of GHG emission.

Now, Profits $=P Q-C\{9\}$. Profits are the residual between revenue (quantity produced, and sold, times the unit (fixed) price $\mathrm{P}$ (in pure competition) and total cost $C$. Inserting in $\{9\}$, equations $\{1\}$ and $\{3\}$, and setting partial derivatives to zero, with respect to the five inputs, we can get also for this for the environment: $\mathrm{P} * \mathrm{MPe}-\mathrm{P} 5=0\{10\}$ for profit maximization or cost minimization: $\mathrm{P} 5=\mathrm{P} * \mathrm{MPe}$ $\{11\}$. Equation $\{11\}$ means that environment can be polluted up to the point where the "value of its marginal product" equals its price (= the unit value of GHG emissions). If a Government wishes to eliminate GHG pollution, then it has to place a tax equal to P5. This amount can be devoted subsequently to support state health system and environmental improvement.

\section{Part V: The Digital Citizen-DC}

Technology made the DC powerful and self-sufficient! Mobile phone-MP is now the instrument for all banking transactions. We all saw the "love affair" developed between DC and MP! MP became a "quasi-ticket" for all mass means of transport (plus a "mass transit transaction model")! Bio-data etc., stored in MPs, will make mobile transactions secure, and simpler, and preferred (77\% of those asked in Greece responded positively). MP will soon show a passport, identity card, birth certificate and driving license etc. All documents will be stored-in and shown-up in a MP, authentically...

Academia is called to play an important role now: to provide re-skilling to people so that to avoid a replacement by a younger person (cheaper, computer-literate). Professionals in computers argued that their knowledge became ob-

\footnotetext{
${ }^{56}$ Meaning the increase in the total quantity of GHG emissions by producing 1 additional unit of product.

${ }^{57} \mathrm{~A}$ fee, starting from $\$ 15$ per metric ton of greenhouse gas (GHG) emission, legislated in USA in 2019 by the "Energy innovation and carbon dividend act" (EICDA).
} 
solete more than 5 times in their life...! Society and academia have to focus also to, the between classes of ages, antagonism. By this we mean the cases, where 1 younger and cheaper employee can replace one expensive at his $40 \mathrm{~s}$ !

More people move now into advanced ages (67+), requiring: home robots, medicines, more houses for the aged, physiotherapists, and services only from a distance to avoid... walking/driving. There is, obviously, no need for more nurseries and primary schools... Personal contacts will be rare, including that of Professors with their students. Interviews, conferences, dates and marriages etc. will be arranged only through social media.

Life will become more home-centered for a number of reasons, one being COVID-19, for the present 1 - 2 years, and another the danger to be killed (Paris 200 dead so far) or robbed, while in: streets, stadiums, subway/Metro, buses, coffee/restaurants, theaters etc. Always someone will attempt to steal one's credit card and wallet. Credit cards will soon become... invisible and readable only by laser...

The DC is: ego-centric. Social distancing will be maintained... as COVID-19 trained us. Voting from distance will be generalized. The DC will be equipped with a high technology, powerful, new smart phone/mobile computer. Schools will be closed-up, as an improved distance learning-resembling/simulating interactive actual classes and much better than today, will be more convenient. Libraries will become book-museums, as whatever one needs will be in the internet $^{58}$.

The DC, but also the present, is a tele-worker. The term "tele-" will accompany everything; tele-pay, tele-buy, tele-love, tele-teaching, tele-phoning etc.! $80 \%$ of firms adopted tele-working (25/10/2020), from 1\% before covid-19, in Greece. The DC looks constantly on a screen (of his/her smart phone, tablet or computer), neither left or right, and everybody else is out of sight... One positive service smart phones and tablets will offer is to photo criminal happenings, disasters or car accidents ${ }^{59} \ldots$

Digitalization (coupled with AI) will be a more general trend, where intelligent machines will take-over, perhaps all, human jobs! Naturally, it will be beneficial if machines will cut-down human time spent in bureaucratic, boring, unproductive and time-consuming jobs...!

Citizens will demand devices for communication like smarter-smaller pocket-sized mobile phones/tablets. In addition: other social media, internets, advanced TV services (e.g. Netflix); improved home cinemas, biometrical watches etc. Also, people will ask for faster cars, better mass transportation and decent health services, especially for the aged. DC will look forwards for: 1) Voice recognition. 2) A small robot to carry-out most or all of the office-jobs. 3) A robot-a "home diagnostic unit"-of all usual analyses ${ }^{60}$. 4) Personal information in 24 hours a day. Calls from 112 (emergency phone of state services for citizen's

\footnotetext{
${ }^{58} \mathrm{~A}$ district attorney in Greece prosecuted people spreading fake news in social media for COVID-19.

${ }^{59} \mathrm{Till}$ replaced by Wi-Fi in mobile phones...

${ }^{60} \mathrm{At}$ the time of writing this we learned that a home test for COVID-19 is a reality.
} 
protection); warnings from fire brigades; real time info about: floods, winds, earthquakes; list of broken-off roads and bridges with maps. 5) Provision of independent water and electricity at times when the permanent providers fail. 6) Advise to stay home or abandon it. 7) Available hospitals and phones. 8) Available ambulances and time of arrival. 9) A robot-home laboratory-measuring radiation, air pollution, water pollution, noise levels, etc. This may also manage cleverly home's electricity and gas consumption. Also, filtering incoming air, reduce humidity, and indicating where home's heating is lost. 10) A robot to tell owner about the state of his/her car, making the proper electronic tests. 11) $A$ robot to act as a personal secretary in cooperation with number 2 . Robots to save one's time, so that to have time to love more those one loves...

\section{Conclusion}

Humanity retarded to admit that its real enemy was not the gradual depletion of $D M$, which never came, or will come, in our opinion, but the extreme bad weathers! COVID-19 proved dangerous also, but only if it is here to stay! Hurricanes are with us since 1780 at least, killing more than 453,000 (Appendix 1). COVID-19 brought certain... beneficial repercussions, but also a number of negative impacts, which we presented.

Humanity has to retain and increase COVID-19's benefits, we believe, when and if virus goes away. Humanity was lucky in its unluckiness, as COVID-19 provided a global experiment of the effects that the use of less transport (private; air; buses etc.), the reduced consumption of energy, tele-working, tele-educating and tele-buying have brought in. It is remarkable that COVID-19 showed how a serious pollution can be eliminated!

Many by now realized in my country (households and shop keepers), that they have to buy a boat... and build a room in a high place. Moreover, house and shop windows and doors have now to be water resistant or, even better, water proof:

Everybody, we reckon, has to become familiar with "weather forces", recognize them, and do whatever is in one's power to avoid them! We all know that climate no more remained as we knew it certain decades ago. We all have experienced the ever-increasing number of summer days at round 40 degrees $\mathrm{C}$ and over for several weeks.

We have now to forget the world we knew, and seriously we have to build it afresh, i.e. to rebuild it absolutely friendly to its citizens! A sustainable city? Cities (=smart) as well houses (=clever) have to become green... All houses have to acquire independent (autonomous) energy from Sun, from winds or from a "home nuclear harmless water unit" ... we learned about a few years back.

Humans did 4 economic revolutions, which mainly concerned with faster quantity of production, under the threat of Malthus. Though humans is not proper to live in order only to eat, the poverty we see is not due to lack of means, but is due to lack of care for our neighbor.

Important conclusion was that companies profited by polluting the environ- 
ment! So, they have to pass it to State till is zero. Our contribution, as mentioned, was to insert environment into production function, where it belongs, so that production can become eventually clean, and to produce zero GHG emissions.

A final conclusion is that we succeeded to transform climate from a friend to an enemy! This has to be reversed as soon as possible. Societies should not roll-over their responsibilities by considering weather accidents as natural... They are human-made. We showed the enemies of our society for which we have to fight. We showed also the future citizen-the digital one-somebody mobile phone addictive and isolated one from the rest. Do we want this type of personality? Technology is a curse and a blessing and we have to be careful. This paper traced-out the steps our society is taking and I am terrified if it takes the wrong direction. I am rather old to see it, but precaution is better than cure. Reject the trend for one to be in autarky from everybody else... from a distance.

\section{Conflicts of Interest}

The author declares no conflicts of interest regarding the publication of this paper.

\section{References}

Arthur, W. B. (1994). Increasing Returns and Path Dependence in the Economy. Ann Arbor, MI: The University of Michigan Press. https://doi.org/10.3998/mpub.10029

Christodoulou, A. (2018). Maritime Environmental Performance Indices: Useful Tools for Evaluating Transport Supplier Environmental Performance? WIT Transactions on The Built Environment, 187, 187-198. https://doi.org/10.2495/MT190171

Common, M. (1995). Sustainability and Policy: Limits to Economics. Cambridge: Cambridge University Press.

Dieren, W. V. (1995). Taking Nature into Account: A Report to the Club of Rome, towards a Sustainable National Income. New York: Copernicus.

Goulielmos, A. M. (2018). Psychological Economics: The Case-Studies of Eurozone, Global Economic Crisis and Greece. Modern Economy, 9, 1792-1820.

Goulielmos, A. M. (2020). From the Dynamics of Population to the Application of Digital Revolution to Management of Shipping Companies. Modern Economy, 11, 1155-1175.

Goulielmos, A. M., Giziakis, C. V., \& Christodoulou, A. (2014a). The Extent of Awareness and Effectiveness of IMO's Air Pollution Measures: The Case of Greek Shipping. Environmental Pollution \& Protection Scientific Journal, 3, 46-58.

Goulielmos, A. M., Giziakis, C. V., \& Christodoulou, A. (2014b). Comparison of the "Global Levy Scheme" with the "Emissions Trading Scheme" to Reduce Greenhouse Gas Shipping Emissions. Environmental Pollution \& Protection Scientific Journal, 3, 91-108.

Meadows, D. H., Meadows, D. L., \& Randers, J. (1992). Beyond the Limits: Global Collapse or a Sustainable Future. London: Earthscan.

Meadows, D. H., Meadows, D. L., Randers, J., \& Behrens, W. W. (1972). The Limits to Growth. New York: Universe Books.

Pearce, D. W. (1992). Macmillan Dictionary or Modern Economics (4th ed.). London: 
Macmillan Education. https://doi.org/10.1007/978-1-349-22136-3_15

Pezzey, J. C. V., \& Toman, M. A. (2002). The Economics of Sustainability. Farnham: Ashgate Dartmouth.

Stopford, M. (2009). Maritime Economics (3rd ed.). Oxon: Routledge. https://doi.org/10.4324/9780203891742

US National Oceanic \& Atmospheric Administration's National Hurricane Center (2019).

World Commission on Environment and Development WCED (1987). Our Common Future. The Brundtland Report, Oxford: Oxford University Press.

Xiao, Q., Chen, L., Xie, M., \& Wang, C. (2020). Optimal Contract Design in Sustainable Supply Chain: Interactive Impacts of Fairness Concern and Overconfidence. Journal of the Operational Research Society. https://doi.org/10.1080/01605682.2020.1727784 


\section{Appendix 1}

We recorded-down the main tropical cyclones etc. (Table A1).

Table A1. A historical account of tropical cyclones, storms etc., 1780-2020.

\begin{tabular}{|c|c|c|c|c|}
\hline Year & Name (type) & Dead & Nation/area & Cost/speed/damages \\
\hline 1780 & The "Great" hurricane & 22,000 & N Atlantic/Lesser Antilles & Not known \\
\hline 1900 & "Galveston" (hurricane) & $\begin{array}{c}6000 \\
12,000\end{array}$ & Texas & \\
\hline 1961 & "Nancy" (typhoon) & - & - & $346 \mathrm{~km} / \mathrm{hour}$ \\
\hline 1970 & "Bhola" (tropical cyclone) & 300,000 & Bangladesh & \\
\hline 1975 & "Nina" (typhoon) & 100,000 & China & 62 dams fell \\
\hline 1979 & “Tip” (typhoon storm) & - & Pacific & $310 \mathrm{~km} /$ hour \\
\hline 1982 & $\begin{array}{l}\text { Tropical depression } \rightarrow \\
\text { "Paul" hurricane eventually }\end{array}$ & 1000 & Central America & \\
\hline 1991 & "Thelma" (tropical storm) & thousands & Philippines & \\
\hline 1992 & "Iniki" (hurricane) & 6 & Hawaii & $\$ 3 \mathrm{~b}$ damages \\
\hline $1993-4$ & "Rewa" (cyclone) & - & S Pacific; Australia & \\
\hline 1994 & “John” (hurricane) & - & North Hem. & 31 days \\
\hline 1996 & "Olivia" (tropical cyclone) & - & Queensland & $408 \mathrm{~km} /$ hour \\
\hline 1997 & "Paka" (typhoon) & - & Guam & $378 \mathrm{~km} /$ hour \\
\hline 2004 & "Gafilo" (cyclone) & 74 & Madagascar & \\
\hline \multirow[t]{5}{*}{2005} & $\begin{array}{l}\text { "Katrina" (hurricane) } \\
\text { (tropical cyclone) }\end{array}$ & 1836 & USA (Louisiana; Mississippi) & $\begin{array}{l}\$ 125 \mathrm{~b} \text { of which } \$ 81.2 \mathrm{~b} \text { in } \\
\text { properties; } \$ 100 \mathrm{~b} \text { damages }\end{array}$ \\
\hline & "Sandy" (tropical cyclone/hurricane) & - & USA & \\
\hline & “Mitch” (hurricane) & $>10,000$ & Central America & \\
\hline & "Pauline" (hurricane) & - & Mexico & \\
\hline & “Kenna” (hurricane) & - & Mexico & \\
\hline 2008 & "Marco" (tropical storm) & - & Veracruz & \\
\hline 2012 & "Maria” (hurricane) & - & USA & Total $\sim \$ 92 \mathrm{~b}$; damages $\$ \sim 69 \mathrm{~b}$ \\
\hline 2013 & "Haiyan" & 6300 & East. Visayas (Philippines) & \\
\hline 2015 & "Patricia" (hurricane) & - & Western Hem. & $346 \mathrm{~km} /$ hour \\
\hline 2017 & "Harvey" (hurricane) & 90 & Texas, USA & $\$ 125 b$ \\
\hline Total 24 & $1780-2017$ & $>453,306$ & & $\$ 345 b$ \\
\hline 2020/Sept.18-20 & "Janus" (cyclone) & 4 & $\begin{array}{l}\text { Greece: Karditsa; Trikala; } \\
\text { Pertouli; Cephalonia; } \\
\text { Ithaca; Karpenisi; Lamia }\end{array}$ & $\begin{array}{l}\text { Winds } 130 \mathrm{klm} / \mathrm{hour} \text {; Pilio } 417 \mathrm{mil} \text {. } \\
\text { rain/day in } 2009 ; 317 \text { tons of water } \\
\text { per acre fell in } 2 \text { days }(2020) ; \\
€ 1 / 2 \text { m damages; } 5000 \text { houses } \\
\text { fell or damaged \& } 2500 \text { shops }\end{array}$ \\
\hline 2020/Sept.-Oct. & Alex & 9 & France Nice-Italy & $\begin{array}{l}\text { Rain fell in } 4 \text { hours } \\
\text { instead of } 6 \text { months }\end{array}$ \\
\hline 2020/Nov. & Goni & & Philippines & $1 \mathrm{~m}$ evacuated; winds of $225 \mathrm{~km} / \mathrm{h}$. \\
\hline
\end{tabular}

Source: data from Wikipedia, downloaded 21/09/2020 for "tropical cyclones", except for the 3 last ones. 